IRA-International Journal of Management \& Social Sciences

ISSN 2455-2267; Vol.05, Issue 03 (2016)

Pg. no. 402-407

Institute of Research Advances

http://research-advances.org/index.php/RAJMSS

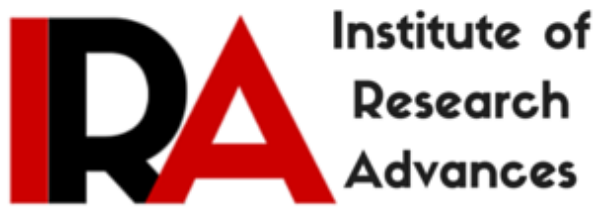

\title{
Khap Panchayats among the Jats of North- West: A Socio-Historical Interpretation of Medieval Period
}

\author{
Dr. Birpal Singh Thenua \\ Assistant Professor (Sociology) \\ Department of Sociology \& Political Science \\ Faculty of Social Sciences \\ Dayalbagh Educational Institute (Deemed University) \\ Dayalbagh, Agra - 5, India.
}

Type of Review: Peer Reviewed.

DOI: http://dx.doi.org/10.21013/jmss.v5.n3.p2

\section{How to cite this paper:}

Thenua, B. (2016). Khap Panchayats among the Jats of North-West: A Socio-Historical Interpretation of Medieval Period. IRA-International Journal of Management \& Social Sciences (ISSN 2455-2267), 5(3), 402-407. doi:http://dx.doi.org/10.21013/jmss.v5.n3.p2

(C) Institute of Research Advances

\section{(c) EY-NC}

This work is licensed under a Creative Commons Attribution-Non Commercial 4.0 International License subject to proper citation to the publication source of the work.

Disclaimer: The scholarly papers as reviewed and published by the Institute of Research Advances (IRA) are the views and opinions of their respective authors and are not the views or opinions of the IRA. The IRA disclaims of any harm or loss caused due to the published content to any party. 


\section{ABSTRACT}

Khap Panchayat is most thirsted area not only for social scientists but most disputed and controversial issue for media persons, social workers and political activists. Our Honorable Supreme Court has made some harsh and strict comments on these Khap Panchayats. Khap Panchayats may be wrong in their functioning and activities in present time but at the time of their origin and in medieval period they did perform a number of social, political, administrative and judiciary functions. They fought against invaders, provided external and internal security to the community. The volunteers of these Khap Panchayats participated in many wars and battles of national interest. These were the by-product of an egalitarian community and were based on the principles of democracy and their functioning was democratic. Most of the decisions were taken in open meetings of Khap Panchayats or Sarva Khap. There was a community democracy during the medieval period before the modern democracy, and this democracy worked for hundreds of year.

\section{KEY TERMS}

Khap, Khap Panchayat, Sarva Khap Panchayat, Clan, Thamba, Caste, Faank, Egalitarian, Democracy, Pargana, Sarkar, Zamidari, Jazia, Panchayat, Bhaichara, Gotra

\section{Introduction of Khap Panchayats}

Now a day 'Khap Panchayat' of north India is most controversial and debating institution amongst the journalists, social workers and media. Historically Khap Panchayat has been a system of social and political administration, since ancient time. Various scholars tracing their origin to tribal times (Kumar 2012). Khap is term for socio-political grouping and used in a geographical sense (Sunita and Yudhvir 2013). The villages inhabited by a clan are organized into clan council, and the area under its jurisdiction is called Khap (Pradhan 1965). Generally, a Khap is consisted as a socio-political unit of 84 villages. The structure of Khap, consisted of 7 villages is Thamba, these 12 Thambas form a unit of 84 villages, called Khap Panchayat. A Khap Panchayat is divided into a number of political sub-units called Thamba Panchayat. A Thamba is comprises with a number of neighboring villages varying from Thamba to Thamba. It is divided into a number of informal Gamvand Panchayats. A group of 5 to 8 neighbouring villages is called Gamvand (Pradhan 1965). The origin of word 'Khap' is derived form 'Faank', meaning as offshoot or fraction. This word was probably first time used in Rajasthan in the context of Rajput rulers, classes, during the medieval period (Bharadwaj 2013). Khap word has extensively used in the context of different sects of Rajasthan ruling class. The first Census report based on religion and caste was prepared in Jodhpur (1890-1891), dividing the people of India on the basis of religion and caste. The castes were divided into Gotras, the word Gotra was termed as Khap (Bharadwaj 2013). The Khap Panchayat, like the caste system and joint family system, is a traditional institution engaged primarily in dispute resolution and in regulating the behaviour of individuals or groups in rural North India (Sangwan 2009). The composition of peasant caste union called Khap (Sharma 2003).

Pachayat has written reference as far back as 2500 BC. Since that time, there had been a shift from nomadic way of life to settled agricultural practices. From this time Indian society was organized into village life. The mode of governing of village life was that of council of five that is called Panchayat. Khap Panchayat means the Panchayat of nearby villagers who belong to common Gotra. The different Gotras had / have their own Khap Panchayats. The studies of village communities and Panchayats were carried out by some western scholars, such as Sir Henry Maine, Baden Pawell, Charls Metcalfe and James Mill all these occupied various posts in the East India Company. These studies were based on the descriptions of the European travelers rather than field work or documents of Mughal period. 


\section{Origin and Development of Khap Panchayats}

Historically speaking, the Khap Panchayats are very old. Exact origin of Khap Panchayats can not be found out but we may broadly consider the period of its development in 600 AD (Rajpurohit \& Prakash 2015; Singhal, Malik \& Malik 2013). But they attracted the attention of scholars only when the electronic media highlighted certain of their decisions which violated the human rights of individuals. These decisions were mainly related to marriages which violated the traditional moral code of conduct, especially the concept of village Bhaichara (brotherhood), Gotra Bhaichara (clan brotherhood) or Khap Bhaichara (brotherhood of persons belonging to same Khap, signifying equality within the Khap), which form the basis of community harmony in Indian villages, especially those in northern India (Sangwan 2009). Khap Panchayats are understood to have come into existence as a social system for maintenance mechanism in agrarian societies. They are the legacies of the tribal councils, formed by various tribes with a purpose of facilitating resolution of intra-tribal disputes and inter-tribal inter-course (Singh 2010). The Sarv-Khap Pancyayat, according to local beliefs, was organized in $7^{\text {th }}$ century by emperor Harsha at Prayag (modern Allahabad). The written historical records of different Khap Panchayats and Sarva Khap Panchayats are evident that there was a meeting $\left(10^{\text {th }}\right.$ Ashad, Samvat 1256,1191 AD) of Sarva Khap Panchayats held at Tikri Village of Meerut which was attended by 60,000 people of various Khaps (Pradhan 1969). If we believe on the handwritten Pothi of Pandit KanhaRam the first meeting of Sarva Khap Panchayat was held in the forest of Baraut in 1195 AD and it was decided in the meeting to raise defense volunteers against the attack of Mahammad Ghori and in Samvat 1254 / 1197 AD against the imposition of Jazia and restrictions over Panchayats by Qutubuddin Aibak (Pradhan 1969). In $13^{\text {th }}$ century Sarva Khap Panchayat Samvat 1258 / 2101 AD expressed concern over the defeat of Rathor Chauhans. During this period Khap Panchayats did protest against state injustice such as imposition of Jazia, ritual bathing and revenue hike, increase taxation, restrictions on Panchayats, severe famine and lawlessness. Further Khap Panchayats became very powerfull when they extended military support to Ibrahim Lodi in 1517 against his brother and Maharana Sangram Singh in 1527 against Babar.

\section{Jats during Medieval Period}

The Jats from the earliest time have been remarkable for the rejection of the monarchical principle and their strong partiality for self governing commonwealth (Irvin 1922). The history of Jats is glorious not only in Mughal period but also in Delhi Saltnat. The informationin from the Chachnama, in 809 AD that Jats reared cattle in the area of Sindh (Chachnama). According notable historian Satish Chandra "The Jat living on the both sides of the river Jamuna has a strong sense of clan brotherhood and egalitarians reflected in their clan brotherhood with culminated in a Chhaap. The Chhaap was somewhat like a tribal Jirga, but was more hierarchical (Chandra 2006). During the phase of Delhi Saltnat, the Jats emerged as an important farmer community in the area of Punjab. Abul Fazl in his Ain-i-Akbari describes that Jat as among the best farmers in the north-western region . Later on, Jat acquired a large number of Zamidaris in Delhi and Agra Subas (Abul Fazl). The French writer Modave Comte writes: Although the Jats are gentle people and if they are not forced to take arm, they tame delight in farming on their fair will. For me, the hard work of the Jats are appreciable because of the facts, that they have not left to earth unploughed and their fields are far better maintained (Comte 1937). The position of Jats during the Mughal period was much strong than that of Saltnat. Ain-i-Akbari (1595AD) had lot of descriptions of Jat Zamidaris. During the $16^{\text {th }}$ century Delhi Suba comprised a total of 8 Sarkars and 232 Parganas, of these 64 Parganas has Jat Zamidars and out of these 27 Parganas the Jat had their shared Zamidaries with other castes. The Agra Suba had a total of 13 Sarkars comprising 203 Parganas. The Jat had their Zamidaris in 22 Parganas and in 17 Parganas the Jats had shared Zamidaris with other castes (Dwivedi 1989). 


\section{Khap Panchayats in Saltnat and Mughal Period}

Khap Panchayats were very strong in Delhi Saltnat and Mughal Period. They have military power to fulfill the interests of their jurisdictions. Certain Delhi Kings as Ibrahim Lodi, Muhammad Shah and a Few others, asked the Wazir of Khap Balian and also of other Khaps to provide military help to crush revolts or the expels the rebels from the kingdom and to keep peace within the Khaps. Such help was provided by the Khaps but only after it was decided in the meeting of the Sarv Khap Panchayat, and the conditions on which the proposed help was to be given were discussed and agreed upon by the representatives of the various Khaps (Pradhan 1965). At the time of invasion of Mohammad Gouri, Taimur, Babar, Ahmad Shah Abdali and so forth, the armies of various Khaps fought against these invaders. Each Time decisions were taken in the open Panchayat meeting in the interests of common defense and freedom. The autobiography of Taimur, Malfuzat-e-Tamuri, tells us that Jats troubled him a lot in the areas around Tohama (near Hisar, Haryana). The Pothi of Pandit KanhaRam tells the meeting of Khap Panchayat was held in 1398 AD in the forest of Chaugama in Muffarnagar to resist the onslaught of the attacks of Taimur Lane. Khap Panchayats extended their support to Ibrahim Lodi in 1517 against his brother by sending defense volunteers. In 1527 Khap Panchayats did help to Maharana Sangram Singh against Babar. This period witnessed the growth of power of Jat Khap Panchayats.

The organization and role of the Khap Panchayats was well recognized during the Mughal period in much clearer terms. Emperor Akbar realized the power of Khap Panchayats and granted freedom to the Khaps in matters of religion and internal administration. Autonomy was given in judiciary matters and their hereditary leaders were recognized by the Delhi court as the leaders of the respective Khaps. They were exempted from taxes and the Khaps were allowed to perform their internal functions with full freedom. A mandate issued by Emperor Akbar said that "every community and the Khaps of the Doab have the freedom to carry out their functions according to their old custom and laws within their respective Khaps". He further stated that these different Khaps may unite in one group and live in peace with each other (Mandate of 8th Ramzan 987 Hizri [1578 AD] emperor Akbar). The mandate (Firman) was issued to Chaudhary Pacchumal of Shoron village and Chaudhary Ladsingh of Sisauli, the Wazir and the headman of Khap Balian respectively (Pradhan 1965). Another Firman (mandate) was issued in the reign of Mughal Emperor Akbar in $11^{\text {th }}$ Ramzan 989 Hijri (1580 AD) by the grand Wazirs Abul Fazal and Raja Todarmal- "By the present Firman (mandate) certain community Panchayats in India who during the reign of the Saltnat (of Delhi) were charged certain taxes before my reign, are now being exempted from such taxes. Every community Panchayat has my permission and is free to carry out its traditional functions in my reign (Pradhan 1965). One of the last mandates issued in 1157 Hijri (1748 AD) to the Khap Wazir was regarding the raising of a military force to help the emperor in maintaining peace in the area, it also simultaneously warned the Khap Wazir that strict action would be taken against any section that revolted against him. Such royal mandates were issued by various Mughal emperors from time to time (Sangwan 2009).

\section{Conclusion}

There is a popular saying, states that Jat Ka Kya Hindu Aur Meo Ka Kya Musalman. This conveys that it is difficult to clearly equate the religion of Jat as Hindu or the religion of Meo as Muslim (Bharadwaj 2013). Jat did not rigidly observe Hindu traditions nor did Meo closely observe Muslim traditions. This saying thus captures the dynamic progressive nature of Jat community. One can say that the Jat community stood apart forms the rigitd boundaries of Brahmanical Hindu traditions. Jat community's socio-cultural traditions and practices did not confirm with the rigid cultural religion of the Hindu caste system (Rana 2003). A number of reform movements as Nathpanthies, Monotheistic ideology of Baba Hiradas, Nischal Das, Garibdas are mainly associated with Jat dominated areas of Harayan and Delhi. Arya Samaj, a modern religious reform movement was popular in Jat areas of North West India. 
Origin of Khap Panchayats was the result of fulfillment of the need of the community, specially pastoral and agrarian community. Till centuries they did perform a number of socio-cultural, political, administrative and judiciary functions. During Saltnat and Mughal period they were very strong and the kings also realized the need and existence of Khap Panchayats. There functioning was democratic, most of the decisions were taken with the consultation of the representatives of different Khaps or the members of the Khap. They were the custodians of social norms and values of the society but time to time they provided external and internal security to the community from invaders. In general Jats are democratically inclined in their behavior.

In the words of Harayana Chief Minister Mr. Manohar Lal Khattar- "they are not formed by the government. These Khap Panchayats are continued from last 900 years. These Panchayats have been made by the people of those areas only. They have carried out various social reforms such as fighting against dowry system; they worked for Beti Bachao Beti Padhao and gender ratio. He further said I rather feel it is a useful instrument of society. It is not as if they indulge is something, which is wrong. Khap is a big Panchayat. One or two mistakes or incidents don't make Khap Panchayats wrong as a whole. Even human beings and institutions commit mistakes. Khap Panchayats have strength of their own" (Khattar 2016).

\section{References}

Abul Fazl, The Ain-i-Akbari. Vol. II. pp. 193-206

> Bharadwaj, S.B. (2013). Myths and Reality of Khap Panchayats: A Historical Analysis of the Panchayats and Khap Panchayat. SAGE

$>$ Chandra, S. (2006) Medieval India: From Sultnat to the Mughals. New Delhi: Har Anand Publications Pvt. Ltd.

$>$ Chachnama; in Elliot and Dowson. (1990). The History of India as Told by its Own Historians. Vol. I. Delhi: Low Price Publication. pp. 190-91

$>$ Chaudhary, D.R. (2013). Khap Panchayaton Ki Prashangikta (Hindi). Delhi: National Book Trust

$>$ Chaudhary, D.R. (2013). Khap Panchayats and Modern Age. Delhi: National Book Trust

$>$ Comte, D. M. The Delhi Empire a Century after Bernier. Translated from the French by Jonathan Sarkar. (1937). in Islamic Culture. Vol. II. July 1937. pp. 387-88

$>$ Dwivedi, G.C. (1989). The Jats, their Roles in Mughal Empire. New Delhi: Maharaja Surajmal Memorial Education Society

$>$ Irvin. W. (1922). Later Mughals. Kolkata: M.C. Sarkar \& Company.

$>$ Khattar, M. (2016). Khap Panchayats are Useful Instruments of Society. The Hindu: Kolkata. (Interview given in Kolkata)

$>$ Kumar, A. (2012). Khap Panchayats: A Socio-Historical Review. Economic \& Political Weekly. Vol. XLVII. No.4. January 28, 2012. pp. 59-64

$>$ Nagla, M. (2014). Khap Panchayats, Honour Killing and Gender Relations in Western India. in Pankaj, A.K. Subalternity, Exclusion and Social Change in India. Foundation Books

$>$ Nazim, M. (1931). The Life and Times of Sultan Mahmud of Ghazna. U.K.: Cambridge University Press

> Pradhan M. C. (1965). The Jats of Northan India: Their Traditional Political System. The Economic Weekly. 11 December 1965.

$>$ Pradhan, M.C. (Ed.). et. al (1969). Anthropology and Archeology. Delhi: Oxford University Press

$>$ Rajpurohit, G.S. \& Prakash, A. (2015). Khap Panchayats in India: Legitimacy, Reality and Reforms. International Journal of Allied Practice, Research and Review. Vol. II. Issue III, pp. 8190

Rana, R.P. (2006). Rebels to Rulers: The Rise of Jat Power in Medieval India 1665-1735. Delhi: Manohar 
$>$ Sangwan, K. S. (2009). Khap Panchayats in Harayana: Sites of Rural Pluralism. in Kannabiran, K. \& Singh, R. (eds.) Challenging the Rule(s) of Law: Colonialism, Criminology and Human Rights in India. Sage Publications PVT LTD

$>$ Sharma, R.S. (2003). Early Medieval Indian Society: A Study in Feudalism. Hyderabad: Orient Longman

$>$ Singh, R. ( 2010 ). The Need to Tame Khap Panchayats. Economic and Political Weekly. Vol. XLV. No. 21. May 22

$>$ Singhal, A.K.; Malik, I. \& Malik, A.K. (2013). Khap Panchayat \& Personal Laws in India. Researcher. 5 (2) pp. 39-43. http://www.sciencepub.net/researcher

$>$ Sunita \& Yudhvir. (2013). Khap Panchayats: Changing Perspectives. Asian Journal of Multidimensional Research. Vol.2. Issue.7. July 2013. pp. 14-20 